\title{
KOMPETENSI PROFESIONALISME GURU INDONESIA DALAM MENGHADAPI MEA
}

\author{
Wahyu Bagja Sulfemi, S.S., M.Pd. \\ Korespondensi: STKIP Muhammadiyah Bogor \\ STKIP Muhammadiyah Bogor: Jalan Raya Leuwiliang No. 106 Bogor 16640 \\ surel:wahyubagja@gmail.com
}

\begin{abstract}
ABSTRAK
Tulisan ini mengkaji mengenai kompetensi profesionalisme guru dalam menghadapi MEA. Metode dalam penulisan ini mendeskripsikan sebuah masalah yang terdapat dalam kemampuan frofesionalisme guru Indonesia dalam menghadapi MEA. MEA merupakan bentuk realisasi dari tujuan akhir integrasi ekonomi di kawasan Asia Tenggara. Pada tahun 2015 kesepakatan Masyarakat Ekonomi ASEAN (MEA) atau Pasar Ekonomi ASEAN mulai berlaku. Kesepakatan ini tak hanya berdampak pada sektor ekonomi, tapi juga sektor-sektor lainnya. Tak terkecuali "pendidikan" sebagai modal membangun sumber daya manusia yang kompetitif. Tantangan MEA dalam dunia pendidikan yang akan dihadapi antara lain, menjamurnya lembaga pendidikan asing, standar dan orientasi pendidikan yang makin pro pasar, serta pasar tenaga kerja yang dibanjiri tenaga kerja asing. Untuk itu era perdagangan bebas ASEAN, harus disambut oleh dunia pendidikan dengan cepat, agar sumber daya manusia Indonesia siap menghadapi persaingan yang semakin ketat dengan negara-negara lain. Kompetensi profesionalisme guru dan mutu institusi pendidikan, dengan demikian menjadi suatu keharusan mutlak serta sekaligus menjadi pasword atau kata kunci untuk melahirkan putra-putri bangsa yang beradab, produktif, kreatif, inovatif dan efektif. Cita dan harapan kelahiran manusia beradab tersebut di atas seharusnya lahir dari suatu institusi pendidikan yang berstandar nasional (SNPI) dan bahkan internasional
\end{abstract}

Kata Kunci : kompetensi profesionalisme, guru, MEA

\section{PENDAHULUAN}

MEA atau Masyarakat Ekonomi ASEAN adalah bentuk sistem perdagangan bebas antara negara-negara di kawasan ASEAN (Asia Tenggara). Perdagangan bebas MEA baru akan ditetapkan pada tahun 2015. Indonesia beserta 9 negara anggota ASEAN seperti Malaysia, Singapura, Thailand, Laos, Myanmar, Filipina, Vietnam, Brunei Darusalam, dan Kamboja telah menyepakati perjanjian Masyarakat Ekonomi ASEAN atau dalam bahasa inggris yaitu ASEAN Economic Community.

Indonesia yang secara geografis berada di ASEAN (Asia Tenggara) maka dengan sendirinya akan masuk dalam Masyarakat Ekonomi ASEAN (MEA). Pembentukan Masyarakat Ekonomi ASEAN (MEA) berawal dari kesepakatan para pemimpin ASEAN dalam Konferensi Tingkat Tinggi (KTT) pada Desember 1997 di Kuala Lumpur, Malaysia. 
Pada KTT selanjutnya yang berlangsung di Bali Oktober 2003, petinggi ASEAN mendeklarasikan bahwa pembentukan MEA pada tahun 2015.

Dalam konteks globalisasi ekonomi, secara de facto kawasan Ekonomi ASEAN memiliki nilai strategis dalam mendorong pertumbuhan ekonomi Asia mengingat Asia memiliki luas wilayah terbesar dunia, yakni $30 \%$ dari total daratan dunia ( sekitar 44 juta KM2), dan jumlah penduduk terbesar, yaitu 4 miliar (Peran dan Strategi Pendidikan Tinggi dalam Menghadapi AEC 2015.html).

Masyarakat Ekonomi ASEAN (MEA) merupakan realisasi tujuan akhir dari integrasi ekonomi yang tertuang dalam visi 2020, dan didasarkan pada konvergensi kepentingan negara anggota ASEAN untuk memperluas integrasi ekonomi melalui inisiatif yang ada. Komunitas ini akan membentuk ASEAN sebagai pasar global dan basis produksi tunggal membuat kawasan ASEAN lebih dinamis dengan mekanisme dan upaya untuk memperkuat pelaksanaan baru yang ada inisiatif ekonomi, memfasilitasi kegiatan bisnis, melakukan percepatan integrasi regional di sektor-sektor prioritas, tenaga kerja yang terampil dan bakat memperkuat kelembagaan mekanisme ASEAN.

Seluruh negara anggota ASEAN telah menyepakati perjanjian ini. MEA dirancang untuk mewujudkan wawasan ASEAN 2020. Dalam menghadapi persaingan ketat selama MEA ini, negara-negara ASEAN haruslah mempersiapkan sumber daya manusia (SDM) terampil, cerdas, dan kompetitif. MEA adalah liberalisisi di semua aspek kehidupan. Tanpa kemampuan memadai menghadapi hal ini maka kita hanyalah akan menjadi penonton, bukan pelaku di era MEA. Kesepakatan ini tak hanya berdampak pada sektor ekonomi, tapi juga sektor-sektor lainnya. Tak terkecuali "pendidikan"

Pendidikan mengemban peran penting dalam membangun sumber daya manusia yang kompetitif dan mampu bersaing dengan negara lain. Oleh karena itu untuk menyambut MEA 2015, pendidikan harus mampu mempersiapkan sumber daya manusia (SDM) yang terampil, peka dan kritis dalam menghadapi tantangan maupun perubahan-perubahan yang akan terjadi di dunia pendidikan mendatang. Tantangan MEA dalam dunia pendidikan yang akan dihadapi antara lain, menjamurnya lembaga pendidikan asing, standar dan orientasi pendidikan yang makin pro pasar, serta pasar tenaga kerja yang dibanjiri tenaga kerja asing.

Menyiapkan sumber daya manusia yang kompetitif memang bukan pekerjaan mudah yang dapat dilakukan secara instant. Akan tetapi, apabila pendidikan di Indonesia mampu membekali siswa dengan pengetahuan serta keterampilan yang memadai, maka lulusan pendidikan Indonesia akan memiliki rasa percaya diri serta motivasi yang tinggi untuk mengembangkan diri secara optimal, sehingga mampu bersaing secara global. Akan tetapi, 
dunia pendidikan di Indonesia masih mempunyai sekian banyak rintangan terkait dengan kualitas pendidikan diantaranya, keterbatasan akses kepada pendidikan, jumlah guru yang belum merata, juga mutu guru itu sendiri yang dinilai masih kurang. Selain itu adalah kemampuan pedagogic guru sebagai garda terdepan dalam meningkatkan sumber daya manusia. Maka dari itu kemapuan pedagoguk guru harus ditingkatkan.

Berdasarkan paparan dari latar belakang di atas dapat dirumuskan permasalahan sebagai berikut : (1) Bagaimana kemaapuan pedagogik guru (2) Bagaimana kompetensi profesionalisme guru Indonesia dalam menghadapi MEA 2015 ?

\section{METODELOGI}

Berdasarkan rumusan masalah di atas, peneliti memilih untuk menggunakan metode diskriptif. Metode penelitian deskriptif adalah salah satu metode penelitan yang banyak digunakan pada penelitian yang bertujuan untuk menjelaskan suatu kejadian. Seperti yang dikemukakan oleh Sugiyono (2011) "penelitian desktiptif adalah sebuah penelitian yang bertujuan untuk memberikan atau menjabarkan suatu keadaan atau fenomena yang terjadi saat ini dengan menggunakan prosedur ilmiah untuk menjawab masalah secara aktual”. Metode dalam penulisan ini mendeskripsikan sebuah masalah yang terdapat dalam kemampuan frofesionalisme guru Indonesia dalam menghadapi MEA

\section{PEMBAHASAN}

MEA merupakan bentuk realisasi dari tujuan akhir integrasi ekonomi di kawasan Asia Tenggara. Terdapat empat hal yang akan menjadi fokus MEA pada tahun 2015 yang dapat dijadikan suatu momentum yang baik untuk Indonesia.

1. Negara-negara di kawasan Asia Tenggara ini akan dijadikan sebuah wilayah kesatuan pasar dan basis produksi. Dengan terciptanya kesatuan pasar dan basis produksi maka akan membuat arus barang, jasa, investasi, modal dalam jumlah yang besar, dan skilled labour menjadi tidak ada hambatan dari satu negara ke negara lainnya di kawasan Asia Tenggara.

2. MEA akan dibentuk sebagai kawasan ekonomi dengan tingkat kompetisi yang tinggi, yang memerlukan suatu kebijakan yang meliputi competition policy, consumer protection, Intellectual Property Rights(IPR), taxation, dan E-Commerce. Dengan demikian, dapat tercipta iklim persaingan yang adil; terdapat perlindungan berupa sistem jaringan dari agen-agen perlindungan konsumen; mencegah terjadinya pelanggaran hak cipta; menciptakan jaringan transportasi yang efisien, aman, dan terintegrasi; 
menghilangkan sistem Double Taxation, dan; meningkatkan perdagangan dengan media elektronik berbasis online.

3. MEA juga akan dijadikan sebagai kawasan yang memiliki perkembangan ekonomi yang merata, dengan memprioritaskan pada Usaha Kecil Menengah (UKM). Kemampuan daya saing dan dinamisme UKM akan ditingkatkan dengan memfasilitasi akses mereka terhadap informasi terkini, kondisi pasar, pengembangan sumber daya manusia dalam hal peningkatan kemampuan, keuangan, serta teknologi.

4. MEA akan diintegrasikan secara penuh terhadap perekonomian global. Dengan dengan membangun sebuah sistem untuk meningkatkan koordinasi terhadap negara-negara anggota. Selain itu, akan ditingkatkan partisipasi negara-negara di kawasan Asia Tenggara pada jaringan pasokan global melalui pengembangkan paket bantuan teknis kepada negara-negara Anggota ASEAN yang kurang berkembang. Hal tersebut dilakukan untuk meningkatkan kemampuan industri dan produktivitas sehingga tidak hanya terjadi peningkatkan partisipasi mereka pada skala regional namun juga memunculkan inisiatif untuk terintegrasi secara global.

Pemerintah telah menerbitkan Instruksi Presiden (Inpres) Nomor 11 Tahun 2011 tentang Pelaksanaan Komitmen Cetak Biru MEA dalam upaya persiapan menghadapi pasar bebas ASEAN. Dalam cetak biru MEA, terdapat 12 sektor prioritas yang akan diintegrasikan oleh pemerintah. Sektor tersebut terdiri dari tujuh sektor barang yaitu industri agro, otomotif, elektronik, perikanan, industri berbasis karet, industri berbasis kayu, dan tekstil. Kemudian sisanya berasal dari lima sektor jasa yaitu transportasi udara, kesehatan, pariwisata, logistik, dan teknologi informasi. Sektor-sektor tersebut pada era MEA akan terimplementasi dalam bentuk pembebasan arus barang, jasa, investasi, dan tenaga kerja.

Sejauh ini, langkah-langkah yang telah dilakukan oleh Indonesia berdasarkan rencana strategis pemerintah untuk menghadapi MEA / AEC, antara lain : (1) Penguatan Daya Saing Ekonomi. (2) Program ACI (Aku Cinta Indonesia). (3) Penguatan Sektor UMKM. (4) Perbaikan Infrastruktur. (5) Peningkatan Kualitas Sumber Daya Manusia (SDM). (6) Reformasi Kelembagaan dan Pemerintahan (http://Persiapan Indonesia Dalam Menghadapi MEA (Masyarakat Ekonomi ASEAN).html)

Melihat dari Data Badan Pusat Statistik (BPS) tahun 2014 di Indonesia menunjukkan bahwa penduduk di atas 15 tahun yang bekerja berdasarkan tingkat pendidikan secara berurutan adalah: SD 46,8\%, SLTP 17,82\%, SLTA 25,23\% dan pendidikan tinggi 10,14\%. Jika dilihat dari data tersebut, lulusan pendidikan dasar lebih mendominasi, oleh karena itu mampukah pendidikan Indonesia menyiapkan sumber daya manusia yang kompetitif dan 
mampu bersaing. (http://Unia Pendidikan Indonesia Menghadapi Masyarakat Ekonodmi ASEAN (MEA) 2015 _ Dina Nur Hayati.html). Jika melihat negara tetangga semisal Singapura dan Malaysia. Survey yang dilakukan PISA untuk mengetahui kemampuan menulis, membaca dan sains anak sekolah menengah, anak Indonesia selalu berada di urutan terbawah jika dibandingkan dua negara jiran itu. Mereka memiliki kurikulum jangka panjang yang jelas. Apa yang hendak dicapai, apa yang harus dilakukan, tepat sasaran dan bisa diukur. Keunggulan lain dari kurikulum kedua negara itu disamping tidak gampang berubah adalah skill yang diperlukan untuk menghadapi era globalisasi termuat gamblang dalam kurikulum mereka. Sehingga tamatan atau lulusan sekolah-sekolah di kedua negara itu lebih mampu menghadapi persaingan global. (Potret Pendidikan Indonesia Menghadapi MEA dan Tantangan Bonus Demografi - KendariNews _ Kendari Pos Online.html)

Berdasarkan fakta peringkat daya saing Indonesia periode 2012-2013 berada diposisi 50 dari 144 negara, masih berada dibawah Singapura yang diposisi kedua, Malaysia diposisi ke dua puluh lima, Brunei diposisi dua puluh delapan, dan Thailand diposisi tiga puluh delapan. Melihat kondisi seperti ini, ada beberapa hal yang menjadi faktor rendahnya daya saing Indonesia menurut kajian Kementerian Perindustrian RI yaitu kinerja logistik, tarif pajak, suku bunga bank, serta produktivitas tenaga kerja.

Dari kondisi tersebut, ke depan diperlukan proses penyadaran dan manajemen yang akurat sehingga dapat menghasilkan tingkat presisinya tinggi, profil guru sebagai orang terdepan menjadi krusial untuk diperhatikan. Guru selama ini memang telah diperlakukan sebagai profesi tetapi perlakuan yang diberikan kepada guru tidak mencerminkan bahwa pekerjaan sebagai guru adalah profesi. Hal ini dapat dilihat dari berbagai penderitaan yang dialami guru dalam melaksanakan tugasnya. Harus disadari bahwa profil guru adalah sebuah tujuan sekaligus alat untuk mencapai tujuan pendidikan, baik tujuan pendidikan secara nasional, institusional, kurikuler maupun proses pembelajarannya.

Kompetensi profesionalisme guru dan mutu institusi pendidikan, dengan demikian menjadi suatu keharusan mutlak serta sekaligus menjadi pasword atau kata kunci untuk melahirkan putra-putri bangsa yang beradab, produktif, kreatif, inovatif dan efektif. Cita dan harapan kelahiran manusia beradab tersebut di atas seharusnya lahir dari suatu institusi pendidikan yang berstandar nasional (SNPI) dan bahkan internasional, serta kerangka kurikulum nasional Indonesia (KKNI). (Meningkatkan Profesionalitas Guru Dan Mutu Pendidikan Menghadapi Masyarakat Ekonomi Asean (MEA) ahyar-fadly.html).

Kompetensi profesionalisme (Professional berasal dari kata sifat yang berarti pencarian dan sebagai kata benda berarti orang yang mempunyai keahlian, seperti dokter, 
hakim. Pekerjaan yang bersifat professional adalah pekerjaan yang hanya dapat dilakukan oleh mereka yang khusus dipersiapkan untuk itu dan bukan pekerjaan yang dilakukan oleh mereka yang karena tidak dapat memperoleh pekerjaan lain. (Sudjana, 2002 : 14).

Profesi guru memiliki karakteristik tersendiri dibandingkan dengan profesi-profesi lainnya, walaupun tugas guru sebagai profesi adalah mendidik, mengajar, dan melatih anak didik, tetapi secara perilaku yang mencerminkan keprofesionalan, seorang guru memiliki tugas yang lebig luas, tidak hanya tugas profesi tetapi juga tugas kemanusiaan dan tugas kemasyarakatan. Oleh sebab itu, tugas dan kedudukan guru dilihat dari segi profesionalisme lebih luas dan terhormat dibanding dengan tugas dan kedudukan guru dilihat dari segi profesi. Hal itu, sesuai dengan motto yang dicetuskan oleh tokoh pendidik kita "Kihajar Dewantara" yaitu Ing ngarso sung tulodo, ing madyo mangun karso, tut wuri handayani (di depan memberi suri tauladan, di tengah-tengah membangun, di belakang memberi dorongan dan motivasi). Dengan demikian kata profesi mengandung dua unsur yaitu unsur keahlian dan unsur panggilan, sehingga orang yang profesional harus memadukan dalam dirinya kecakapan teknik dan kematangan etik yang diperlukan untuk menjalankan pekerjaannya.(Anoraga, 1998: $69-70)$

Guru sebagai profesi merupakan pekerjaan yang menuntut keahlian. Artinya, pekerjaan sebagai guru tidak bisa dilakukan oleh orang yang tidak terlatih dan tidak disiapkan. Kegiatan pendidikan dan pembelajaran di sekolah terhadap peserta didik tidak bisa dilakukan sembarang orang, karena untuk melakukan tersebut dituntut keahlian atau kompetensi sebagai guru. Sebagai profesi, guru harus dapat merebut kepercayaan publik melalui peningkatan kualitas guru dan pelayanan pendidikan dan pembelajaran. Kepercayaan menjadi faktor kunci dalam mengokohkan identitas guru.

Ada beberapa ciri pokok pekerjaan yang bersifat profesional diantaranya : 1) Pekerjaan dipersiapkan melalui proses pendidikan dan latihan secara formal, 2) Pekerjaan tersebut mendapat pengakuan dari masyarakat, 3) Adanya organisasi profesi, dan 4) Mempunyai kode etik sebagai landasan dalam melaksanakan tugas dan tanggung jawab pekerjaan profesi tersebut. Sudjana, $2002: 14)$

Dalam Undang-Undang Sisdikna Nomor 20 Tahun 2003, Profesi guru merupakan bidang pekerjaan khusus yang dilaksanakan berdasarkan prinsip tertentu, yaitu : (1) Memiliki Bakat, minat, panggilan jiwa, dan idealisme (2) Memiliki komitmen untuk meningkatkan mutu pendidikan, keimanan, ketakwaan, dan akhlak mulia (3) Memiliki kualifikasi akademik dan latar belakang pendidikan sesuai dengan bidang tugas. (4) Memiliki kopetensi yang diperlukan sesuai dengan bidang tugas. (5) Memiliki tanggung jawab atas pelaksanaan tugas 
keprofesionalan. (6) Memperoleh penghasilan yang ditentukan sesuai dengan prestasi kerja. (7) Memiliki kesempatan untuk mengembangkan keprofesionalan secara berkelanjutan dengan belajar sepanjang hayat. (8) Memiliki jaminan perlindungan hukum dalam melaksanakan tugas keprofesionalan. (9) Memiliki organisasi profesi yang mempunyai kewenangan mengatur hal-hal yang berkaitan dengan tugas keprofesionalan guru.

Menurut PP RI No. 19/2005 tentang Standar Nasional Pendidikan Pasal 28, pendidik adalah agen pembelajaran yang harus memiliki empat jenis kompetensi, yakni kompetensi pedagogik, kepribadian, profesional, dan sosial. Dalam konteks itu, maka kompetensi guru dapat diartikan sebagai kebulatan pengetahuan, keterampilan dan sikap yang diwujudkan dalam bentuk perangkat tindakan cerdas dan penuh tanggung jawab yang dimiliki seseorang guru untuk memangku jabatan guru sebagai profesi. Keempat jenis kompetensi guru yang dipersyaratkan adalah sebagai berikut: 1). Kompetensi Kepribadian 2). Kompetensi Pedagogik 3). Kompetensi Profesional .4). Kompetensi Sosial

Kompetensi kepribadian merupakan kemampuan personal yang mencerminkan kepribadian yang mantap, stabil, dewasa, arif, dan berwibawa, menjadi teladan bagi peserta didik, dan berakhlak mulia. Secara rinci setiap elemen kepribadian tersebut dapat dijabarkan menjadi subkompetensi dan indikator esensial sebagai berikut: (1) Memiliki kepribadian yang mantap dan stabil. Subkompetensi ini memiliki indikator esensial: bertindak sesuai dengan norma hukum, bertindak sesuai dengan norma sosial, bangga sebagai pendidik, dan memiliki konsistensi dalam bertindak sesuai dengan norma; (2) Memiliki kepribadian yang dewasa. Subkompetensi ini memiliki indikator esensial: menampilkan kemandirian dalam bertindak sebagai pendidik dan memiliki etos kerja sebagai pendidik; (3) Memiliki kepribadian yang arif. Subkompetensi ini memiliki indikator esensial: menampilkan tindakan yang didasarkan pada kemanfaatan peserta didik, sekolah, masyarakat dan menunjukkan keterbukaan dalam berpikir dan bertindak; (4) Memiliki kepribadian yang berwibawa. Subkompetensi ini memiliki indikator esensial: memiliki perilaku yang berpengaruh positif terhadap peserta didik dan disegani; (5) Memiliki akhlak mulia dan dapat menjadi teladan. Subkompetensi ini memiliki indikator esensial: bertindak sesuai dengan norma religius (imtaq, jujur, ikhlas, suka menolong), dan memiliki perilaku yang diteladani peserta didik.

Kompetensi pedagogik merupakan kemampuan yang berkenaan dengan pemahaman peserta didik dan pengelola pembelajaran yang mendidik dan dialogis. Secara substantif kompetensi ini mencakup kemampuan pemahaman terhadap peserta didik, perancangan dan pelaksanaan pembelajaran, evaluasi hasil belajar, dan pengembangan peserta didik untuk mengaktualisasikan berbagai potensi yang dimilikinya. Secara rinci masing-masing elemen 
kompetensi pedagogik tersebut dapat dijabarkan menjadi subkompetensi dan indikator esensial sebagai berikut: (1) Memahami peserta didik. (2) Merancang pembelajaran, (3) Melaksanakan pembelajaran. (4) Merancang dan melaksanakan evaluasi pembelajaran. (5) Mengembangkan peserta didik untuk mengaktualisasikan berbagai potensi yang dimilikinya.

Kompetensi profesional merupakan kemampuan yang berkenaan dengan penguasaan materi pembelajaran bidang studi secara luas dan mendalam yang mencakup penguasaan substansi isi materi kurikulum mata pelajaran di sekolah dan substansi keilmuan yang menaungi materi kurikulum tersebut, serta menambah wawasan keilmuan sebagai guru. Secara rinci masing-masing elemen kompetensi tersebut memiliki subkompetensi dan indikator esensial sebagai berikut: (1) Menguasai substansi keilmuan yang terkait dengan bidang studi. Subkompetensi ini memiliki indikator esensial: memahami materi ajar yang ada dalam kurikulum sekolah, memahami struktur, konsep dan metode keilmuan yang koheren dengan materi ajar, memahami hubungan konsep antarmata pelajaran, dan menerapkan konsep-konsep keilmuan dalam kehidupan sehari-hari; (2) Menguasai langkah-langkah penelitian dan kajian kritis untuk menambah wawasan dan memperdalam pengetahuan/materi bidang studi.

Kompetensi sosial berkenaan dengan kemampuan pendidik sebagai bagian dari masyarakat untuk berkomunikasi dan bergaul secara efektif dengan peserta didik, sesama pendidik, tenaga kependidikan, orangtua/wali peserta didik, dan masyarakat sekitar. Kompetensi ini memiliki subkompetensi dengan indikator esensial sebagai berikut: (1) Mampu berkomunikasi dan bergaul secara efektif dengan peserta didik. Subkompetensi ini memiliki indikator esensial: berkomunikasi secara efektif dengan peserta didik; (2) Mampu berkomunikasi dan bergaul secara efektif dengan sesama pendidik dan tenaga kependidikan; (3) Mampu berkomunikasi dan bergaul secara efektif dengan orang tua/wali peserta didik dan masyarakat sekitar.

Proses belajar mengajar hakikatnya adalah pergaulan antara manusia, baik antara guru dengan siswa maupun antara siswa dengan siswa. Berdasarkan hal itu faktor yang memegang peranan penting dalam iklim belajar mengajar adalah faktor hubungan manusia. Hal yang penting dalam konteks ini adalah kualitas hubungan guru dengan siswa. Kualitas ini ditunjukkan jika hubungan mampu memberikan kesempatan kepada individu untuk mengembangkan diri dengan segala kemungkinan yang dimilikinya. Jadi, iklim dan interaksi belajar mengajar dikatakan kondusif jika memberikan kemudahan bagi siswa untuk mengembangkan diri seoptimal mungkin. 
Sebagai leader di kelas, guru membangkitkan semangat belajar peserta didiknya agar tidak cukup hanya belajar di sekolah saja, tetapi juga mereka akan selalu mengulanginya di rumah atau mencari dari sumber lain seperti pada pendidikan nonformal. Sebagai fasilitator, guru sudah seyogianya ahli dan menguasai secara utuh bidang studi yang diajarkannya, karena guru dituntut memberikan contoh mengenai banyak cara mengatasi bagi peserta didiknya yang mengalami kesulitan, terutama pada peserta didiknya yang berusaha mendalami mata pelajaran yang diajarkannya. Sebagai pembimbing, guru dituntut memberikan perhatian kepada peserta didiknya yang mendapatkan kesulitan dalam belajar, dengan penuh kesungguhan dan penuh tanggung jawab. Sebagai pengelola kegiatan belajar mengajar, dalam hal ini guru perlu mengerahkan semua sumber, mendayagunakan semua potensi serta fasilitas yang berhubungan dengan proses belajar mengajar di kelas. Sebagai agen pembaharuan, dalam hal ini guru dituntut untuk aktif mengambil inisiatif serta kreatif untuk dapat membuat pembaharuan pendidikan sesuai dengan perkembangan ilmu pengetahuan dan teknologi dan kecenderungan yang bakal terjadi dalam masyarakat. Untuk itu guru seyogianya tidak lepas dari informasi yang terjadi sehari-hari, terutama informasi yang berhubungan dengan mata pelajaran yang menjadi bidang ajarnya.

Mengajar merupakan tugas menantang dan kompleks karena yang dihadapi adalah manusia yang masing-masing memiliki karakteristik berbeda tetapi tetap harus dijamin mencapai keberhasilan. Oleh karena itu, seorang guru memiliki peran supermulti, yaitu sebagai pendidik, pengajar, pelindung, dll yang secara rinci dikatakan bahwa profesi guru harus memiliki kemampuan sebagai berikut:

Menguasai bahan ajar. Kelas merupakan suatu organisasi yang semestinya dikelola dengan baik, mengacu pada fungsi-fungsi administrasi yang ada, maka berlaku perencanaan, pengorganisasian, pembagian tugas, penentuan staf, pengarahan, pengkoordinasian, pengkomunikasian dan penilaian. Apa yang dilakukan guru mengacu pada tujuan organisasi, yaitu tujuan sekolah yang merupakan penjabaran dari tujuan pendidikan nasional.

Memahami secara mendalam peserta didik yang dilayani. Guru diharapkan bukan sebagai penyampai materi belaka, tetapi sebagai sosok yang mengenali sacara detil siswa didiknya baik yang normal maupun sisi kelainannya, menguasai teori-teori perkembangan anak, struktur dan dinamikanya.

Mengusai teori dan keterampilan keguruan. Siswa adalah manusia yang memiliki potensi untuk berkembang dan terus berubah, oleh karena itu guru diharuskan mengusai teoriteori yang berkaitan dengan bidang keguruan seperti pemahaman yang berkaitan dengan 
falsafah dan ilmu pendidikan, penguasaan prinsip dan prosedur keguruan yang berkaitan dengan materi yang dibina.

Memiliki kemampuan memperagakan unjuk kerja. Guru sebagai agen pembelajaran dituntut mampu mengelola kegiatan belajar mengajar secara efektif dan efisien baik secara individu maupun kelompok sehingga tujuan pendidikan dapat dicapai dengan optimal. Memiliki sikap, nilai dan kecenderungan kepribadian yang menunjang pelaksanaan tugastugas sebagai guru dan pendidik. Memiliki kemampuan melaksanakan tugas-tugas profesional dan tugas-tugas administratif rutin dalam rangka pengoperasian sekolah disamping kemampuan untuk mengambil bagian dalam kehidupan kesejawatan di lingkungan sekolah. (Supriadi, $2003: 821-822$ )

Kini sebagai dampak sinergi dari perkembangan teknologi komunikasi dan informasi serta perubahan yang lebih demokratis dan terbuka menghasilkan suatu tekanan dan tuntutan terhadap kompetensi guru dalam mendayagunakan teknologi komunikasi tersebut dan pertanggung jawabannya. Oleh karena itu guru dituntut siap berkompetisi dalam membelajarkan siswa mulai menganalisis, merencanakan, mengembangkan, mengimplementasikan dan menilai pembelajaran yang berbasis pada penerapan teknologi pendidikan. Disamping, itu kemampuan guru dalam hal merencanakan pembelajaran, mengelola kegiatan individu, menggunakan multi metode dan memanfaatkan media, berkomunikasi interaktif dengan siswa, (Purwanto, $2001: 1$ )

Terkait dengan hal di atas, menurut Arifin bahwa untuk guru di Indonesia dipersyaratkan memiliki : 1. Dasar ilmu yang kuat sebagai pengejawantahan terhadap masyarakat teknologi dan masyarakat ilmu pengetahuan, 2. Penguasaan kiat-kiat profesi berdasarkan riset dan praksis pendidikan yaitu ilmu pendidikan sebagai ilmu praksis bukan hanya merupakan konsep-konsep belaka. Pendidikan merupakan proses yang terjadi di lapangan dan bersifat ilmiah, 3. Pengembangan kemampuan profesional berkesinambungan, profesi guru merupakan profesi yang terus berkembang dan berkesinambungan.(Ani M. Hasan, $2003: 5$ )

Peranan guru dalam proses belajar mengajar lebih luas dari sekedar sebagai pengajar dengan menggunakan pendekatan instruksional. Dalam konsep baru proses belajar mengajar, guru mempunyai tugas merangsang, membimbing, dan memberikan fasilitas bagi siswa untuk mencapai tujuan yang berarti. Jadi, tugas dan tanggung jawab guru selain sebagai perencana, pengelola, pengevaluasi juga sebagai pemberi motivasi, pembimbing, dan fasilitator. Selanjutnya dinyatakan bahwa guru modern mempunyai tanggung jawab untuk melihat segala 
sesuatu yang terjadi dalam kelas sebagai sesuatu yang bermanfaat untuk menungkatkan perkembangan anak.

Dengan memfokuskan pandangan bahwa guru merupakan pelaksana proses belajar mengajar, guru dituntut mengorganisasikan dan mengatur lingkungan kelas sedemikian rupa sehingga terjadi proses belajar. Guru yang mengorganisasikan dan mengatur lingkungan sehingga terjadi proses belajar pada peserta didik, menurut Darmodihardjo memiliki peran sebagai motivator, fasilitator, pembimbing, evaluator, pengembang materi pelajaran, pengelola proses belajar mengajar, dan agen pembaharuan.( Darmodihardjo, 1990: 11-13).

Sebagai motivator, guru membangkitkan semangat belajar peserta didiknya agar tidak cukup hanya belajar di sekolah saja, tetapi juga mereka akan selalu mengulanginya di rumah atau mencari dari sumber lain seperti pada pendidikan nonformal. Sebagai fasilitator, guru sudah seyogianya ahli dan menguasai secara utuh bidang studi yang diajarkannya, karena guru dituntut memberikan contoh mengenai banyak cara mengatasi bagi peserta didiknya yang mengalami kesulitan, terutama pada peserta didiknya yang berusaha mendalami mata pelajaran yang diajarkannya. Sebagai pembimbing, guru dituntut memberikan perhatian kepada peserta didiknya yang mendapatkan kesulitan dalam belajar, dengan penuh kesungguhan dan penuh tanggung jawab. Sebagai pengelola kegiatan belajar mengajar, dalam hal ini guru perlu mengerahkan semua sumber, mendayagunakan semua potensi serta fasilitas yang berhubungan dengan proses belajar mengajar di kelas. Sebagai agen pembaharuan, dalam hal ini guru dituntut untuk aktif mengambil inisiatif serta kreatif untuk dapat membuat pembaharuan pendidikan sesuai dengan perkembangan ilmu pengetahuan dan teknologi dan kecenderungan yang bakal terjadi dalam masyarakat. Untuk itu guru seyogianya tidak lepas dari informasi yang terjadi sehari-hari, terutama informasi yang berhubungan dengan mata pelajaran yang menjadi bidang ajarnya.

Untuk dapat melaksanakan peran tersebut, guru seyogianya memiliki kemampuan dasar tertentu. Kemampuan dasar guru mencakup semua ilmu pengetahuan, keterampilan serta sikap yang harus dan dapat dilakukan guru dalam penyelenggaraan proses belajar mengajar. Kemampuan dasar yang diperoleh selama menjalani pendidikan di LPTK merupakan modal utama untuk bisa mengajar. Kemampuan tersebut seyogianya terus dikembangkan agar menghasilkan kualitas pengajaran yang baik. Kemampuan dasar tersebut meliputi sepuluh kemampuan dasar guru dalam hal : (1) Penguasaan materi; (2) Pengelolaan PBM; (3) Penggunaan media dan sumber; (4) Pengelolaan kelas; (5) Menguasai landasanlandasan kependidikan ; (6) Mengelola interaksi belajar mengajar; (7) Menilai prestasi belajar siswa untuk kepentingan pengajaran ; (8) Mengenal fungsi dan program bimbingan 
dan penyuluhan ; (9) Mengenal dan menyelenggarakan administrasi; (10) Memahami prinsipprinsir dan mampu menafsirkan hasil-hasil penelitian pendidikan untuk keperluan pengajaran.

Peranan guru dalam proses belajar mengajar lebih luas dari sekedar pengajar dengan menggunakan pendekatan instruksional. Jadi, tugas dan tanggung jawab guru selain perencana, organisator, evaluator ditambah motivator dan pembimbing serta fasilitator. Selanjutnya dinyatakan bahwa guru modern mempunyai tanggung jawab untuk melihat segala sesuatu yang terjadi dalam kelas sebagai sesuatu yang bermanfaat untuk meningkatkan perkembangan anak. Berkaitan dengan tugas dan tanggung jawab guru tersebut, maka pendekatan yang dipergunakan dalam proses belajar mengajar tidak saja melalui pendekatan instruksional tetapi disertai pendekatan pribadi. Melalui pendekatan pribadi ini diharapkan guru dapat lebih memahami siswa sehingga dapat membantu kelancaran proses belajar mengajar.

Guru mempunyai tugas dan tanggung jawab mengembangkan keseluruhan pribadi siswa. Bila mengajar hanya menggunakan pendekatan instruksional, maka tujuan itu tidak akan tercapai karena pendekatan instruksional lebih cenderung mengembangkan aspek intelektual. Menurut Darmodihardjo ada tiga tugas pokok guru dalam pendidikan. Ketiga tugas tersebut adalah sebagai berikut:

Pertama, tugas profesi yaitu tugas yang berkaitan dengan profesi. Tugas ini mencakup tugas mendidik (untuk mengembangkan pribadi siswa), mengajar (untuk mengembangkan intelektual siswa), melatih (untuk mengembangkan keterampilan siswa) dan mengelola ketertiban sekolah sebagai penunjang ketahanan sekolah.

Kedua, tugas manusiawi (human responsbility), yaitu tugas sebagai manusia. Dalam hal ini, guru bertugas mewujudkan dirinya, dalam arti merealisasikan seluruh potensi yang dimilikinya melalui auto identifikasi dan auto pengertian untuk dapat menempatkan dirinya didalam keseluruhan manusia sesuai dengan martabat manusia.

Ketiga, tugas kemasyarakatan (civil mission), yaitu tugas guru sebagai anggota masyarakat dan warga negara dalam hal ini bertugas membimbing siswa menjadi warga negara yang baik sesuai dengan kaidah-kaidah yang terdapat dalam pancasila, UUD 1945, dan GBHN. (Natawidjaja, $1984: 61$ )

Guru sebagai kunci keberhasilan pendidikan memiliki tugas, peranan dan tanggung jawab yang besar. Keberhasilan dalam menjalankan peranan, tugas dan tanggung jawab tidak saja ditentukan oleh kecakapannya dalam mengajar tetapi yang lebih penting adalah kepribadian guru. Hal itu disebabkan komunikasi guru dengan siswa bersifat verbal dan bukan 
verbal. komunikasi verbal dalam bentuk personifikasi jauh lebih penting, karena guru sebagai objek identifikasi dan imitasi siswa.

Menurut Loree ada tiga komponen yang terlibat dalam proses belajar mengajar, yaitu komponen stimulus, organisme, dan respon. Komponen stimulus adalah faktor-faktor yang merangsang terjadinya perilaku belajar. Komponen stimulus ini terdiri atas: (1) bariabel pengalaman belajar, yang meliputi metode (motivasi, bimbingan guru, praktek reinforcement); variabel tugas (keluasan, kesulitan, dan kebermaknaan);dan konteks lingkungan, berupa kondisi dimana kegiatan belajar itu berlangsung. Komponen organisme terdiri dari faktor-faktor yang ada dalam diri siswa, yaitu: (1) karakteristik siswa, seperti kecerdasan, usia, jenis kelamin, status sosial ekonomi; dan (2) proses mediasi, seperti ingatan, berpikir, menerima, pengalaman, kecemasan, frustasi atau stres. Sedangkan komponen respon adalah tujuan-tujuan pendidikan yang ingin dicapai, terdiri dari kognitif, afektif dan psikomotor.

Proses belajar mengajar hakikatnya adalah pergaulan antara manusia, baik antara guru dengan siswa maupun antara siswa dengan siswa. Berdasarkan hal itu faktor yang memegang peranan penting dalam iklim belajar mengajar adalah faktor hubungan manusia. Sedangkan menurut Chaplin suatu interaksi dikatakan berkualitas jika mampu memberikan kesempatan kepada individu untuk mengembangkan diri dengan segala kemungkinan yang dimilikinya. (JP. Chaplin, 1993 : 436) Jadi, iklim belajar mengajar dikatakan kondusif jika memberikan kemudahan bagi siswa untuk mengembangkan diri seoptimal mungkin.

Kepribadian guru lebih penting dari pengetahuan dan keterampilan yang dimilikinya, karena kepribadian guru merupakan dasar bagi perilakunya. Kecenderungan guru dalam menggunakan model mengajar, kepemimpinan dan sikapnya terhadap siswa akan diwarnai oleh kepribadiannya. Hal ini seperti diungkapkan oleh Bernard mengungkapkan bahwa iklim kelas dipengaruhi oleh berbagai faktor diantaranya kurikulum, metode, bangunan, bahan pengajaran, masyarakat dan siswa. Tetapi yang terpenting adalah guru, yang dalam hal ini adalah kepribadiannya.

Dengan melihat hal tersebut maka ada beberapa hal yang harus diperhtikan Pendidik dalam menghadapi MEA, Pertama, Potensi Guru Perlu Dikembangkan Hadapi MEA. Dalam menghadapi Masyarakat Ekonomi Assean (MEA) maka harus disiapkan Sumber Daya Manusia (SDM) yang baik, terutama untuk menyiapkan kualitas siswa yang baik maka potensi guru yang perlu dikembangkan. Dalam menghadapi MEA nanti tentu banyak tantangan yang nantinya dihadapi bagi dunia pendidikan, sehingga sejak awal sudah harus 
mempersiapkan diri terutama para guru harus mempunyai kualitas dan mempunyai kapabilitas yang bisa implementasinya bukan sebatas regional namun sampai pada tingkat nasional.

Apabila berhadapan dengan MEA tentunya banyak yang harus dipersiapkan karena nantinya berhadapan dengan orang-orang dari luar negeri maka untuk SDM harus lebih baik dan siap menghadapi semua tantangan itu. Oleh karena itu, dari Diknas juga tidak sekedar hanya duduk diam namun harus menyiapkan sumber SDM yang handal, terutama bagi kebanyakan sekolah. Untuk itu, dirinya berharap agar dapat menyiapkan SDM secara baik dan berkualitas itu juga akan mengedepankan sekolah, sebagai Diknas hanya mengeluarkan regulasi-regulasi ataupun aturan-aturan tetapi secara proporsional itu dilaksanakan oleh sekolah, informasi yang sudah diketahui oleh kepala-kepala sekolah, sehingga pihak sekolah juga tentu sudah mengambil langkah dalam menghadapi MEA nanti.

Menurut Muhdar, agar terbentuknya SDM siswa secara baik maka seharusnya diawali dari guru karena yang melakukan perbaikan di sekolah adalah guru dan kepala sekolah sedangkan untuk pengawas hanya mengawasi dan Diknas hanya menurunkan regulasi untuk selanjutnya secara proposional adalah sebagai ujung tombak hanyalah sekolah sendiri dalam hal ini yang juga guru sebagai peran utama dalam peningkatan kualitas siswa. Sehingga guru diharapkan jangan sekedar duduk berpangku tangan namun harus berpikir bahwa kedepan persaingan semakin ketat oleh karena itu potensi yang ada pada guru harus dikembangkan jangan pernah puas dengan ilmu yang dimiliki tetapi terus belajar dan terus kembangkan kompetensi demi untuk masa depan anak didik di sekolah.

\section{KESIMPULAN}

\section{A. Simpulan}

Dari paparan atau uraian di atas dapat diambil beberapa kesimpulan:

1. Meningkatkan kualitas tenaga kependidikan atau profesionalisme dan mutu lembaga pendidikan harus terus dilakukan dan tidak boleh jalan di tempat untuk dapat bersaing dengan lembaga pendidikan bermutu luar negeri yang sudah ada.

2. Kompetensi profesionalisme guru dan mutu institusi pendidikan, dengan demikian menjadi suatu keharusan mutlak serta sekaligus menjadi pasword atau kata kunci untuk melahirkan putra-putri bangsa yang beradab, produktif, kreatif, inovatif dan efektif. Cita dan harapan kelahiran manusia beradab tersebut di atas seharusnya lahir dari suatu institusi pendidikan yang berstandar nasional (SNPI) dan bahkan internasional 
3. Dalam menghadapi Masyarakat Ekonomi Assean (MEA) maka harus disiapkan Sumber Daya Manusia (SDM) yang baik, terutama untuk menyiapkan kualitas siswa yang baik maka potensi guru yang perlu dikembangkan.

4. Dalam menghadapi MEA nanti tentu banyak tantangan yang nantinya dihadapi bagi dunia pendidikan, sehingga sejak awal sudah harus mempersiapkan diri terutama para guru harus mempunyai kualitas dan mempunyai kapabilitas yang bisa implementasinya bukan sebatas regional namun sampai pada tingkat nasional.

\section{Saran}

1. Ada Masyarakat Ekonomi Asean (MEA) Pemerintah Indonesia sudah seharusnya lebih meningkatkan mutu pendidik.

2. Untuk menghadapi tantangan persaingan Masyarakat Ekonomi Asean (MEA) pemerintah Indonesia berkewajiban untuk memajukan lembaga-lembaga pendidikan baik dari tingkat Sekolah Dasar sampai perguruan tinggi, dalam pendidikan formal maupun nonformal, dengan menyediakan berbagai fasilitas pendidikan, termasuk kesejahteraan para tenaga pendidik, sehingga dapat meningkatkan spirit para tenaga pendidik maupun para anak didik.

3. Bagi para guru harus terus meningkatkan Kompetensi profesionalisme agar dapat mencetak para lulusan yang berkualitas bisa diandalkan dalam dunia lapangan kerja dan tidak kalah bersaing dengan para lulusan dari lembaga pendidikan negara Asean lainnya.

\section{Daftar Pustaka}

Anoraga, Panji. (1998). Psikologi Kerja. Jakarta: Rineka Cipta.

Arsyad, dan Sulfemi, Wahyu Bagja. (2014). Minat Siswa Tentang Keadministrasian dengan Hasil Belajar Administrasi Perkantoran. Edutecno. 9 (2), 40-50.

Badar, Dadan Samsul dan Sulfemi, Wahyu Bagja. (2014). Pengaruh Rasa Percaya Diri dan Motivasi Berprestasi Terhadap Kinerja di Kecamatan Ciampea Kabupaten Bogor. Edutecno. 10 (1), 1-10,

Fajartriani, Tia dan Sulfemi, Wahyu Bagja. (2014). Pengaruh Motivasi Kerja Guru dan Iklim Organisasi Terhadap Kinerja Guru SMA Negeri di Kecamatan Cigudeg. Edutecno. 8 (1), 17-26

Sudjana, Nana, (2002). Dasar-Dasar Proses Belajar Mengajar. Bandung: Sinar Baru, Supriadi, Dedi, (2003). Guru Di Indonesia, Pendidikan, Pelatihan dan Perjuangannya Sejak Zaman Kolonial Hingga Era Reformasi. Jakarta: Depdiknas. 
Sulfemi, Wahyu Bagja., (2007). Ilmu Sosial Dasar. Bogor : STKIP Muhamadiyah Bogor.

Sulfemi, Wahyu Bagja. (2013). Pengaruh Persepsi Siswa atas Kemampuan Pedagogik Guru dan Motivasi Belajar Siswa Terhadap Prestasi Belajar Ilmu Pengetahuan Sosial Siswa (Survei di SMK Swasta Kabupaten Bogor). Edutecno. 7 (2), 17-26.

Sulfemi, Wahyu Bagja. (2014). Pengaruh Motivasi dan Lingkungan Sekolah Terhadap Prestasi Belajar Sejarah Di SMA Negeri Leuwilang Kabupaten Bogor. Fascho : Kajian Pendidikan dan Sosial Kemasyarakatan 9 (2), 42-52.

Sulfemi, Wahyu Bagja. (2015). Pengaruh Metode Pembelajaran Kontekstual dan Penggunaan Media Video Pendidikan Terhadap Hasil Belajar IPS. Edutecno. 13 (2), 1-10.

Sulfemi, Wahyu Bagja. (2015). Challenges Of Indonesian Teacher Competence in dealing with Asean Economic Cummunity (AEC). Engglis Forum. 1 (1), 69-79

Sulfemi, Wahyu Bagja. (2016). Hubungan Persepsi Peserta Didik Tentang Kompetensi Guru Mata Pelajaran Sejarah dengan Hasil Belajar Mata Pelajaran Sejarah di Kelas X SMA Negeri 1 Pamijahan Kabupaten Bogor. Fascho, 5 (2), 52-70.

Sulfemi, Wahyu Bagja. (2016). Hubungan antara Persepsi Guru pada Kepemimpian Kepala Sekolah dan Motivasi Guru dengan Kinerja guru dalam Proses Pembelajaran di SMA Negeri 1 Ciomas. Fascho : Kajian Pendidikan dan Sosial Kemasyarakatan, 5 (1), 36-55.

Supriadi, Dedi, (2003). Guru Di Indonesia, Pendidikan, Pelatihan dan Perjuangannya Sejak Zaman Kolonial Hingga Era ReformasiJakarta: Depdiknas.

Purwanto, (2002). Profesionalisme Guru, Teknodik No. 10/VI/Oktober/2002.

Rakhmat, Jalaluddin, (1999). Psikologi Komunikasi, Bandung: Remaja Rosdakarya,

https://astikip.wordpress.com/artikel/sikap-guru-profesional/

http://arifah-suryaningsih.blog.ugm.ac.id/2014/10/11/guru-menuju-masyarakat-ekonomi asean/

http://www.kompasiana.com/imamsubkhan/guru-lokal-kompetensi global_55d2b2c39fafbde50927f2ae

http://www.tettytanoyo.com/2014/09/sudah-siapkan-kita-menghadapi.html

http://Persiapan Indonesia Dalam Menghadapi MEA (Masyarakat Ekonomi ASEAN).html 